\title{
War and Peace
}

\section{Roland Littlewood}

Published online: 7 October 2011

(C) Springer Science+Business Media, LLC 2011

First, the theoretical. Robin Fox is our most outstanding biosocial figure in social anthropology. 'Outstanding' in that he uses insights and evidence from his own fieldwork, and stays close to the central concerns of the disciplinekinship theory, modes of thought and social structurebefore he interprets these through a Darwinian lens. He is truly the heir to the evolutionary anthropologists of the nineteenth century, of whom Tylor is our most typical representative. In doing this, Fox lays himself open to the usual critiques of the evolutionary approach: that it can never be empirical and relies on a conjectural history which can be cherry-picked for relevance, and of course its popular pessimism-social problem $\mathrm{x}$ is because our late Paleolithic genes persist in a twenty-first century environment.

You either like this evolutionary approach or, as with the great functionalists (Durkheim, Malinowski, Radcliffe-Brown), you don't. Some of us tip our toes in every now and then, and here I must plead guilty having just published a piece arguing that psychosis and religion are subserved by the same historical modules, (Theory of Mind and Agent hyper identification).

But, I am a little confused by the abstract (Reading the whole book of course makes more sense but we are here limited to interpreting one chapter). Fox is advising us to take the old modes of thought into account. But what are old, what the new? There seems always to have been some sort of balance between his oppositions - communitas and structure, equality and individual recognition, myth and linear reason, analogical and dialogical, concrete and abstract.

R. Littlewood $(\bowtie)$

Department of Anthropology and Department of Mental Health

Sciences, University College London,

Gower Street,

London WC1E 6BT, UK

e-mail: r.littlewood@ucl.ac.uk
(Personally I like personalistic and naturalistic which we can use both for local ways of thinking as well as our own analytical procedures.) Now Fox seems to be arguing that the first of each pair is the more ancient, and that there has been a variable passage to the second, though the first still persists. Is this passage purely social? But the first is biologically constrained in evolution. Is the second then less "biological", more fragile and vulnerable, as his citing of Boehm would argue? So we have constantly to work at this, if not fighting the Old Adam, at least to accommodate him to our preferred, social, recent and civilized, ways of thinking and acting.

And here we come to the practical. The idea that boredom leads to war gives me the shivers. Persuasive perhaps for World War One, is it true for all violent conflict? If this is plausible, we are faced with a cathartic rather than a behavioural problem. How can we attenuate something like war, but which is not so extreme, into civil life? (And is male sexuality inherently violent?: this makes good biological sense.) The candidate for the 'something like war' is obviously sport. And here I'll recount my own work on blood feuds in Albania. The starting point was the effects of Serbian violence on people in Kosovo but various agencies, were already doing work there on 'trauma' in the early 2000's. My question then was what sort of violence was more 'traumatic', so I turned to look at the institutionalised blood feuds of independent Albania. Similar patterns were once found in Kosovo, Greece, Sicily and indeed the whole Mediterranean/ Middle East region. Blood feuds in Albania were traditionally standardised according to the customary law of the Kanun of Lekë Dukagjini. Vengeance murder was precisely ordered, tit for tat, and only on males above 9 years old. The chosen victim was ambushed, verbally challenged but immediately shot, the body was turned to face his natal village and the victim's own rifle was placed by his hand. The assassin then 
went back to his village and sent a mediator to the victim's house to arrange a period of pledged truce - during which he (the assassin) attended the funeral and wake of the victim. Then the truce ended ...

With the breakdown in public order following the end of communism in Albania, this highly structured system was resurrected to deal with ancient and new conflicts, but the pattern of assassination threatened to descend into fairly indiscriminant family murder with automatic weapons, often drug related. But with the help of the local bishop (along with the imam, a traditional feud mediator) I was able to carry out some interviews with families engaged in old-style feuds. To my surprise, these people seemed relatively untraumatised and phlegmatic: "Well, I told our Pjetar, it's your turn now, go and avenge your brother". So Pjetar goes off, sometimes reluctant, sometimes enthusiastic, to kill in his turn. For those concerned there was a curious inevitability about the whole thing; they pursued mediation - which could have ended the feud-half reluctantly. And they did not seem especially traumatised although it seemed to me the women were less keen than the men. And, on the whole, they kept to the rules.
My immediate feeling was that this was something like a game of cricket. No strong emotions evident yet at some level it obviously provided satisfaction and justice; a test of individual courage; a sense of doing your duty by your clan; and like cricket it went on a long time! So do we return to some sort of Homeric battle of champions, summit meetings with gladiators? Or just simply to symmetrical warfare with its prescribed laws, personnel and isolated place of conflict? (Spectators to the battle of Leipzig took picnics.)

So, was Nietzsche right? Has the triumph of the Christian slave been too dangerous for us all? If representative gladiators sound totally daft, the alternative might be global extinction. In a choice between the behaviourists (let us educate people to be peaceful) and those favouring catharsis (let it out), I might just favour the latter.

Roland Littlewood is Professor of Anthropology and Psychiatry, and a Crabtree Scholar, at University College London. He is author of eight books and two hundred papers in medical and psychiatric anthropology. He has conducted fieldwork in Trinidad, Haiti, Lebanon, Albania and Italy and is Past-President of the Royal Anthropological Institute. 